\title{
Development of an RT-PCR for High Plains virus Indexing Scheme in New Zealand Post-Entry Quarantine
}

\author{
B. S. M. Lebas, F. M. Ochoa-Corona, D. R. Elliott, Z. Tang, and B. J. R. Alexander, Plant Environmental Labora- \\ tory, Biosecurity New Zealand, Ministry of Agriculture and Forestry, P.O. Box 2095, Auckland 1015, New Zealand
}

\begin{abstract}
Lebas, B. S. M., Ochoa-Corona, F. M., Elliott, D. R., Tang, Z., and Alexander, B. J. R. 2005. Development of an RT-PCR for High Plains virus indexing scheme in New Zealand post-entry quarantine. Plant Dis. 89:1103-1108.

High Plains virus (HPV) causes a potentially serious economic disease of cereals and is of quarantine importance for New Zealand. HPV is transmitted by the wheat curl mite Aceria tosichella, and neither the virus nor its vector is present in New Zealand. Cereal seeds imported to New Zealand are required to be certified HPV-free, as the virus is a regulated pest. A procedure was developed for inspecting plants and testing cereal seedlings in quarantine using reverse transcriptase polymerase chain reaction (RT-PCR) as a detection method. A sample of 50,655 sweet corn seeds was taken from an imported commercial line and germinated in containment. Symptomatic seedlings were collected at 3 and 4 1/2 weeks after sowing. Eight out of 27 symptomatic samples tested HPV positive by RT-PCR and were confirmed by enzyme-linked immunosorbent assay (ELISA). Sequence analysis revealed that the HPV isolates had a 99.3 to $100 \%$ nucleotide identity and 99.0 to $100 \%$ amino acid similarity with the HPV USA isolate (GenBank accession no. U60141). HPV variants were detected by single stranded conformational polymorphism (SSCP) analysis but not by restriction fragment length polymorphism (RFLP).
\end{abstract}

High Plains virus (HPV) causes a recently described disease first found in corn and wheat crops in the High Plains regions (Texas, Kansas, Idaho, Colorado, Nebraska, and Utah) of the United States $(9,10)$. The virus has since been found in Florida (USA), Israel, Brazil, Chile, and possibly China and Australia (7).

Electron microscopy studies of HPVinfected leaves of maize and wheat revealed very fine filamentous particles in crude sap preparation and large double membrane particles (DMP) of 150 to 200 $\mathrm{nm}$ diameter in the cytoplasm of all leaf cell types, which may be of viral origin (1). Preliminary data indicate that the HPV genome consists of at least four dsRNA of approximately 900 to 2,400 nucleotides (8). A partial sequence of RNA3, which is believed to encode a putative viral coat protein of $32 \mathrm{kDa}$, was directly deposited to the GenBank database (accession no. U60141) (8). More recently, the Nterminal sequence of the $32-\mathrm{kDa}$ protein was determined by mass spectrometry, and an additional 18 amino acid residues compared with the published sequence U60141

Corresponding author: B. S. M. Lebas

E-mail: benedicte.lebas@maf.govt.nz

* The $e$-Xtra logo stands for "electronic extra" and indicates that Figure 1 appears in color online.

Accepted for publication 7 June 2005.

DOI: 10.1094/PD-89-1103

(C) 2005 The American Phytopathological Society were identified and located at the $\mathrm{N}$ terminus (23). The amino acid sequence analysis of the $32-\mathrm{kDa}$ protein of another five HPV isolates originating from different states of the United States revealed some variability (22). The amino acid sequence did not show any significant homology with any proteins from databases, suggesting that HPV may belong to a possible new virus group (23).

The host range of HPV includes cheat grass (Bromus secalinus L.), wheat (Triticum aestivum L.), barley (Hordeum vulgare L.), oat (Avena sativa L.), rye (Secale cereale L.), maize (Zea mays L.), and some weeds such as yellow foxtail (Setaria glauca L.) and green foxtail (S. viridis (L.) P. Beauv.) (21). HPV symptoms may be confused with those caused by Wheat streak mosaic virus (WSMV; genus Tritimovirus), which has a similar but wider host range (21). However, HPV symptoms can be much more severe than WSMV. HPV symptoms range from mottling, chlorosis, necrosis, and severe stunting to rapid death of the plant depending on environmental conditions, plant genotypes, and time of infection (13). Seed lines of highly susceptible genotypes often die within 2 weeks of infection (15).

HPV was successfully mechanically transmitted from HPV-infected sap by vascular puncture inoculation of seed (5) but not by rub inoculation onto maize seedling leaves (10). HPV is transmitted by the wheat curl mite Aceria tosichella Keifer (20), which is also the vector for WSMV. The two viruses are often found in mixed infections (10). The transmission of HPV isolates by A. tosichella from different regions is variable (19). HPV isolates may or may not be transmitted depending on the mite origin (19). HPV has also been reported to be seed-transmissible. Forster et al. (5) reported a seed transmission rate of three infected corn seeds out of 38,473 seeds $(0.008 \%)$. However, preliminary data from a recent study showed that $4 \%$ of sweet corn seeds from Colorado, USA, were found HPV-positive by indirect enzyme-linked immunosorbent assay (ELISA) (3).

Some workers $(1,10,11)$ reported that a number of eriophyid mite species transmitted diseases, including HPV, wheat spot mosaic, rose rosette, thistle mosaic, fig mosaic, pigeon pea sterility, and redbud yellow, that produce large double membrane-bound bodies in infected cells. These pathogens of still-unknown etiology may constitute a possible new group.

HPV cereal and weed hosts are present in New Zealand; however, neither HPV nor A. tosichella have been reported in this country. Cereals are important crops for New Zealand, with total gross farm-gate values of NZ\$97 million, NZ\$93 million, $\mathrm{NZ} \$ 61$ million, and NZ\$28 million for wheat, barley, maize grains, and other cereals, respectively, for the year ended 30 June 2003 (M. Doak, MAF Policy, personal communication). Consequently, it is important for New Zealand agriculture to import certified HPV-free cereal seeds, as this is the most likely means of spread into the country.

Regulations for the importation of cereal seeds into New Zealand require that they be tested for HPV. No test is specified, but the use of a reliable indexing method such as ELISA and reverse transcriptase polymerase chain reaction (RT-PCR) is implied. An indirect protein A sandwich (PAS-ELISA) and Western blot analysis have been developed for identifying HPV and WSMV (13). ELISA reagents are available from Agdia (Elkhart, IN, USA) for WSMV, but the HPV ELISA assay was under development at the time of this investigation. The partial sequence of the RNA3 from the GenBank database (accession no. U60141) was the only sequence available at the time of our experiment in 2002. However, no PCR protocol has been published. This paper outlines an experiment developed for testing seeds in quarantine using RT-PCR as a detection method. 


\section{MATERIALS AND METHODS}

Seed source and positive controls. Because the transmission of HPV by seeds is variable $(3,5)$, a core sample of 50,655 sweet corn seeds cv. Madonna from the United States was selected to have a $95 \%$ confidence for detecting the disease with a transmission rate of $0.008 \%$ (5). Seeds were sown in 50 trays containing sterile peat in a quarantine level 3 glasshouse $\left(25^{\circ} \mathrm{C}\right.$ during the day and $15^{\circ} \mathrm{C}$ during the night) on 23 August 2002. The HPV positive control was provided by M. G. Redinbaugh (USDA-ARS Corn and Soybean Research).

Inspection. A symptom field guide was produced from pictures available from the website created by S. G. Jensen (www.ianr.unl.edu/ianr/plntpath/nematode/ PPATHPER/Hpv.htm). Two inspections were carried out at 3 and $41 / 2$ weeks from the date of sowing (seedlings at the threeto four-leaf and five- to six-leaf stages, respectively). Seedlings showing chlorotic leaf spots were collected for testing and labeled with an alphabetic letter, prefixed with number 1 or 2 , corresponding to the first and second inspection, respectively.

Sample preparation. After each inspection, leaf samples were immediately weighed ( $0.1 \mathrm{~g}$ for PCR and $0.5 \mathrm{~g}$ for ELISA), preserved by vacuum-drying in glass vials, and stored at $4^{\circ} \mathrm{C}$ until required for testing. Total RNA was extracted from dried leaf samples using the Qiagen plant RNeasy kit following manufacturer's instructions.

Oligonucleotide primers designed for HPV. Specific primers were designed from the RNA3 HPV sequence (GenBank accession no. U60141) using the Primer3 Webinterfase software (17) and tested in silico with Vector NTi software and the NCBIBLAST (http://www.ncbi.nlm.nih.gov/ BLAST/).

The primers were predicted to be free of self-secondary structure, dimers, and hairpin loops according to the Vector NTi individual analysis output. No heteroduplexes were predicted after primer duplex analysis. The NCBI-Blast analysis of both reverse and forward primers did not generate nonspecific matches; thus no plant or other virus products were predicted. The expected PCR product size was 339 bp from nt 277 to 615 of the RNA3 nucleoprotein gene sequence. Primer HPV-F1 (5'TTTATGGCTCTTTGTATTGG-3') binds nt 277 and 296, and primer HPV-R1 (5'TATGTTTCCCCTCTTTGTG-3') binds nt 597 and 615.

RT-PCR. The RT protocol was adapted from Invitrogen (Carlsbad, CA, USA) using the SuperScript II RNase H-Reverse Transcriptase. The denaturation mix $(8 \mu \mathrm{l})$ containing $1 \times$ First-Strand Buffer, $40 \mathrm{U}$ RNaseOUT, $0.25 \mu \mathrm{M}$ HPV-R1 primer, and $2 \mu \mathrm{RNA}$ was incubated for $10 \mathrm{~min}$ at $70^{\circ} \mathrm{C}$ and left at room temperature for 15 $\min$. The transcriptase mix $(2 \mu \mathrm{l})$ containing $0.01 \mathrm{M}$ DTT, $10 \mathrm{U}$ RNaseOUT, 0.5 $\mathrm{mM}$ dNTPs, and $50 \mathrm{U}$ SuperScript was added to the denatured mix and incubated for $1 \mathrm{~h}$ at $42^{\circ} \mathrm{C}$. PCR was performed in a $20-\mu \mathrm{l}$ volume reaction containing $2 \mu \mathrm{l}$ cDNA, $1 \times$ Taq reaction buffer A, $1.5 \mathrm{mM}$ $\mathrm{MgCl}_{2}, 0.2 \mu \mathrm{M}$ HPV-R1 primer, $0.25 \mu \mathrm{M}$ HPV-F1 primer, $0.2 \mathrm{mM}$ dNTPs, and $1 \mathrm{U}$ Taq polymerase (Promega, Madison, WI, USA). Amplification was performed using a GenAmp 9700 PCR thermocycler (Applied Biosystems, Foster City, CA, USA) as follows: one step of denaturation $\left(94^{\circ} \mathrm{C}, 2\right.$ $\mathrm{min}), 30$ cycles of denaturation-annealingelongation steps $\left(94^{\circ} \mathrm{C}, 30 \mathrm{~s} ; 53^{\circ} \mathrm{C}, 30 \mathrm{~s}\right.$; $72^{\circ} \mathrm{C}, 30 \mathrm{~s}$ ), and a final elongation step $\left(72^{\circ} \mathrm{C}, 5 \mathrm{~min}\right)$. The amplified products were analyzed by agarose gel electrophoresis and stained with ethidium bromide.

Restriction fragment length polymorphism (RFLP). Restriction enzymes were used to distinguish differences in HPV isolates generated from the 339-bp PCR reactions. VspI and $\mathrm{H} s p 92 \mathrm{II}$ restriction sites were identified in the published HPV sequence using BCM WebCutter internet software (http://searchlauncher.bcm.tmc. edu/seq-util/seq-util.html). The VspI site was found at nt 65 corresponding to fragment sizes of 65 and $246 \mathrm{bp}$, and two Hsp92II sites were found at nt 103 and 266 , corresponding to band sizes of 35 , 103 , and $163 \mathrm{bp}$.

Restriction reactions $(20 \mu \mathrm{l})$ were carried out using $10 \mu \mathrm{l}$ PCR products, $1 \times$ restriction enzyme buffer, $0.1 \mu \mathrm{g} / \mu \mathrm{l} \mathrm{BSA}$, and $50 \mathrm{U}$ restriction enzyme (Promega). The mixture was incubated for $3 \mathrm{~h}$ at $37^{\circ} \mathrm{C}$. The digested PCR products were analyzed by agarose gel electrophoresis and stained with ethidium bromide.
Single stranded conformational polymorphism (SSCP). SSCP analysis was performed directly on the PCR products of all eight ELISA-positive samples produced from four different PCR reactions using the SSCP protocol described by Rubio et al. (18). The separated single-stranded DNA was silver stained according to the protocol published by Flores and Llacer (4).

Cloning and sequencing. Samples $2 \mathrm{~A}$ and $2 \mathrm{C}$, representing the two different SSCP polymorphisms, were cloned and sequenced. Amplified products were purified using the Quantum Prep Freeze ' $N$ Squeeze DNA gel extraction spin columns (Bio-Rad, Hercules, CA, USA) and cloned using the TOPO TA Cloning kit (Invitrogen). Plasmid DNA was purified using Wizard Plus DNA purification system (Promega) and sequenced using ABI PRISM automated DNA sequencer (Applied Biosystems) at the Centre for $\mathrm{Ge}$ nomics and Proteomics, School of Biological Sciences, University of Auckland, New Zealand. The nucleotide sequences obtained from six different clones were analyzed by and compared with HPV isolate U60141 using the Clustal V method from the MegAlign package (DNA Star, Madison, WI, USA).

ELISA. Preserved sweet corn leaves were sent to Agdia diagnostic services for validation testing. A F(ab')2 ELISA using horseradish peroxidase streptavidin as conjugate was also trialed. The $\mathrm{F}\left(\mathrm{ab} \mathrm{b}^{\prime}\right) 2$ ELISA protocol, HPV antiserum, and positive control were provided by M. G. Redinbaugh (USDA-ARS Corn and Soybean Research). The HPV antiserum was raised in rabbits against a purified fraction from HPV-infected plants that contained a 32$\mathrm{kDa}$ protein similar to that seen by Jensen and co-workers using a standard protocol (6). $F\left(a b^{\prime}\right) 2$ ELISA was carried out as described (12) using a 1:400 dilution of antisera. A sample was considered positive if the absorbance means of a sample was higher than the absorbance means of negative control plus three times the standard deviation of the negative control.

\section{RESULTS}

Inspection. During visual inspections, 27 of $50,655(0.54 \%)$ sweet corn seedlings grown in glasshouse conditions had
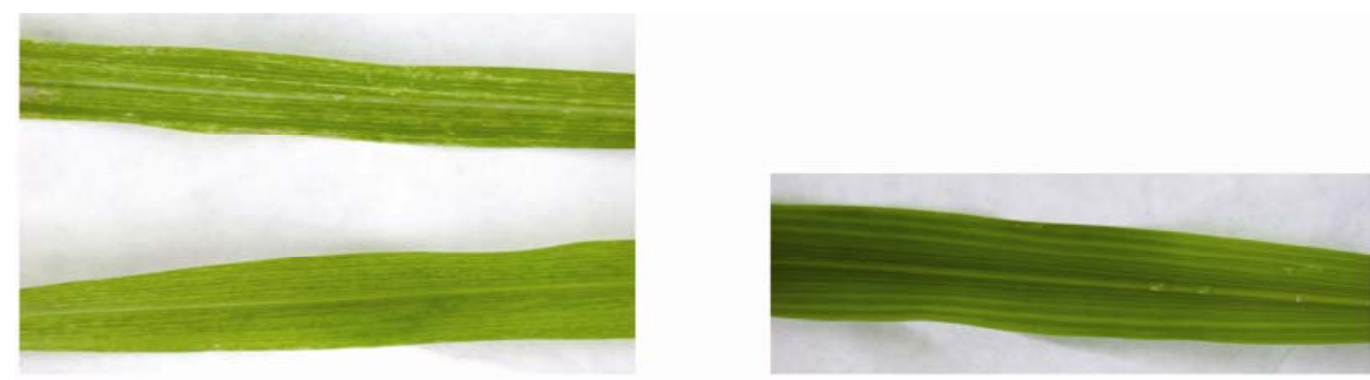

Fig. 1. Chlorotic streaking on sweet corn leaves infected with High Plains virus (left) compared with a healthy control (right) at $41 / 2$ weeks from date of sowing. 
chlorotic streak-like symptoms and were collected for HPV testing (Fig. 1).

RT-PCR diagnosis. The predicted PCR products of $339 \mathrm{bp}$ (Fig. 2) were obtained using HPV primers developed in our laboratory. HPV was detected by RT-PCR up to a dilution of 1:100 of the total RNA (Fig. 2 ). The RT-PCR results revealed that $1 / 15$ and 7/12 samples from seedlings at three- to four-leaf and five- to six-leaf stages, respectively, were HPV positive (Fig. 3). The same results were obtained by ELISA.

RFLP and SSCP studies. All PCR products were restricted at the expected recognition sites using VspI and Hsp92II enzymes (data not shown). However, SSCP analyses revealed two polymorphisms within the HPV-infected samples (Fig. 4).

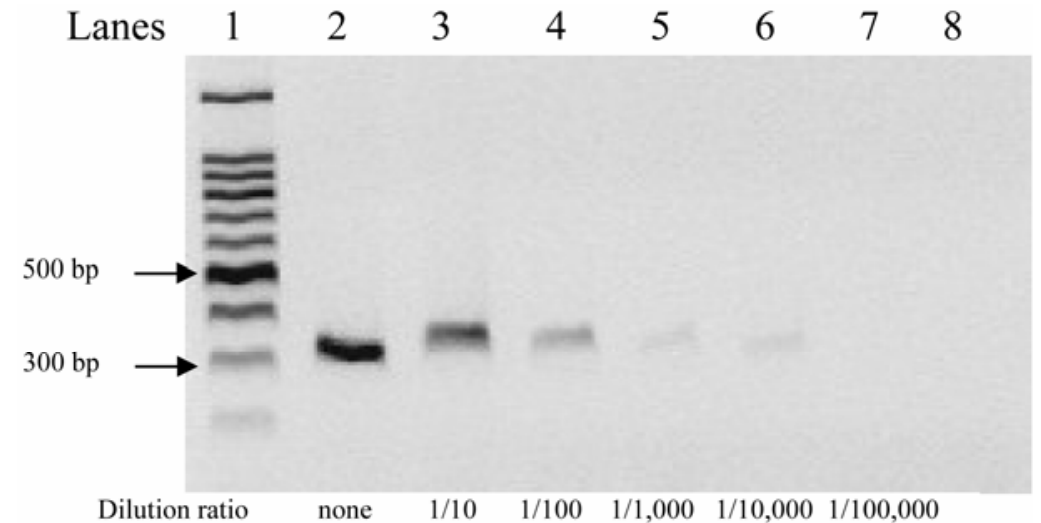

Fig. 2. Reverse transcriptase polymerase chain reaction (RT-PCR) amplification of serial dilution of total RNA from High Plains virus (HPV)-infected tissue using specific primers designed to the RNA3 polyprotein. Lane 1: 100-bp ladder, lane 2: no dilution, lanes 3 to 7, dilution ratios 1:10, 1:100, $1: 1,000,1: 10,000$, and 1:100,000, lane 8: water control.
Seven samples $(1 \mathrm{G}, 2 \mathrm{C}, 2 \mathrm{D}, 2 \mathrm{E}, 2 \mathrm{~F}, 2 \mathrm{G}$, 2J) collected from the indexing experiment and the HPV-positive control had one polymorphism, whereas one sample $(2 \mathrm{~A})$ showed two polymorphisms (Fig. 4).

Sequence analysis. Six clones from one HPV isolate of each SSCP group (samples $2 \mathrm{~A}$ and $2 \mathrm{C}$ ) were sequenced and analyzed (Fig. 5). The same nucleotide sequences were obtained for two clones from sample 2A (c2, c3) and four clones from sample $2 \mathrm{C}(\mathrm{c} 2, \mathrm{c} 4, \mathrm{c} 5, \mathrm{c} 6)$, and only clone $2 \mathrm{~A}-\mathrm{c} 2$ is represented. Nucleotide alterations were found at positions 179, 207, and 223 from 2A clones, and at positions 11 and 16 from 2C clones (Fig. 5). They showed 99.3 to $100 \%$ nt identity and 99.0 to $100 \%$ amino acid similarity to each other and to the HPV isolate available from the GenBank database (U60141). The sequences of one clone each from samples $2 \mathrm{~A}$ (clone 2A-1) and 2C (clone 2C-1) were deposited at the GenBank database (AY836524, AY836525). Nucleotide alterations resulted in four amino acid substitutions at positions 4, 5, 60, and 69 (Fig. 5).

ELISA validation. All HPV RT-PCR positive samples $(1 \mathrm{G}, 2 \mathrm{~A}, 2 \mathrm{C}, 2 \mathrm{D}, 2 \mathrm{E}, 2 \mathrm{~F}$, 2G, 2J, and HPV-positive control) were confirmed by Agdia's ELISA diagnostic

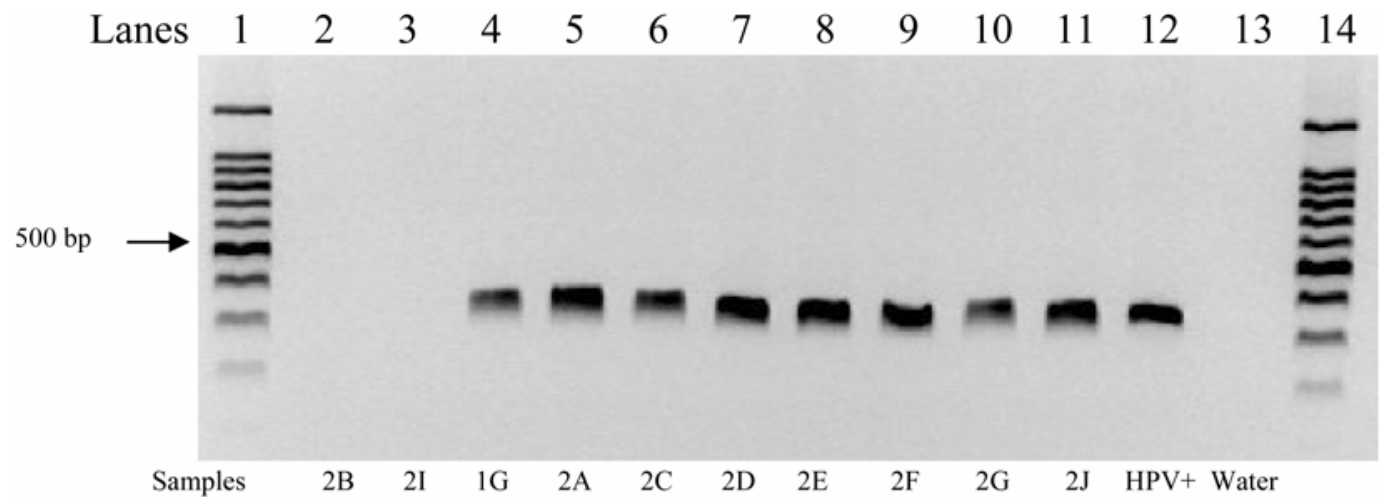

Fig. 3. Polymerase chain reaction (PCR) products of 339 bp obtained using High Plains virus (HPV)-specific primers designed to the RNA3 polyprotein. Lanes 1 and 14: 100-bp ladder, lanes 2 and 3: HPV-negative sweet corn samples 2B to 2I, lanes 4 to 11: HPV-positive sweet corn samples 1G, 2A, 2C, 2D, 2E, 2F, 2G, 2J, lane 12: HPV-positive control, and lane 13: water control.

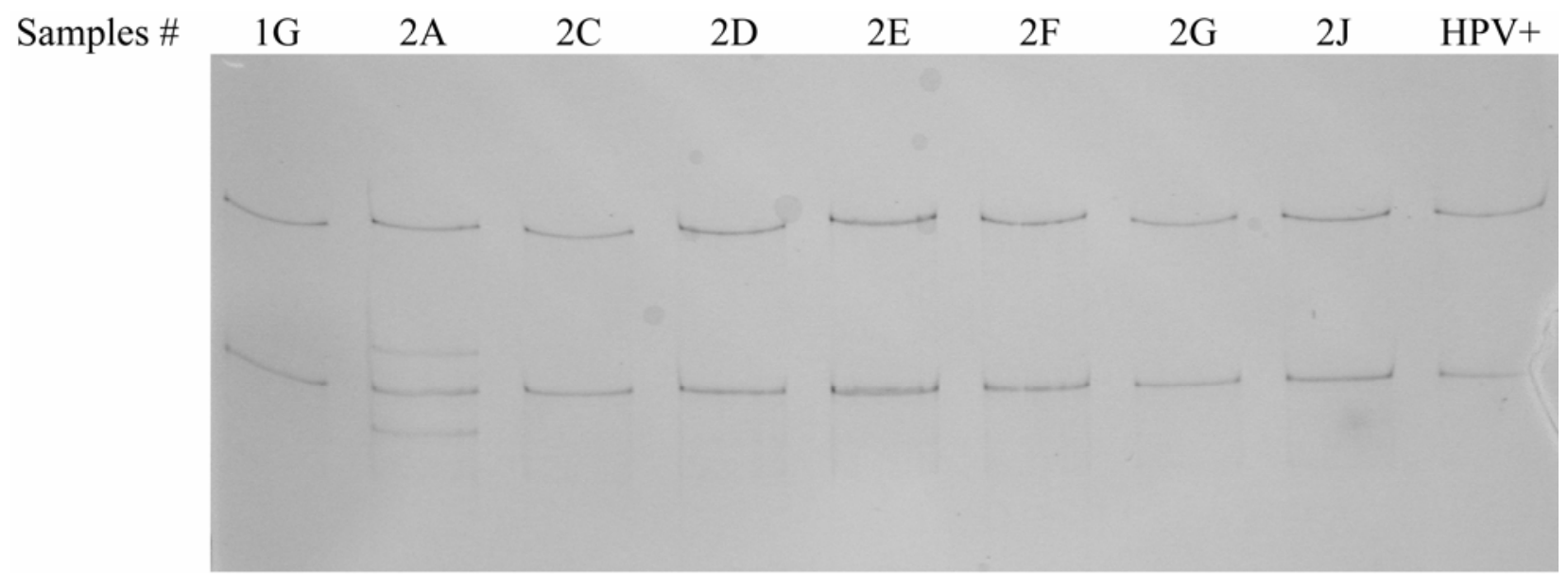

Fig. 4. Single-stranded conformational polymorphism (SSCP) analysis of High Plains virus (HPV) isolates. Seven samples (1G, 2C, 2D, 2E, 2F, 2G, 2J) from the inspection and the HPV-positive control (HPV+) belong to one group, and only one sample (2A) belongs to another group. 
services. Similar results were obtained with the $\mathrm{F}(\mathrm{ab}$ ') protein A ELISA, but a weak absorbance reading was occasionally observed for some of the samples (data not shown). HPV RT-PCR negative samples also tested negative by both ELISA systems.

\section{DISCUSSION}

As directed by the New Zealand import regulations, sweet corn seeds from overseas must be tested for HPV using an ap- propriate inspection procedure and reliable indexing methods. Due to the need of a molecular diagnostic technique for the testing of HPV, an RT-PCR was developed for detecting HPV from seedlings grown in quarantine. HPV-F1 and HPV-R1 primers were designed from the RNA3 sequence (GenBank U60141), which may contain some conserved regions as suggested by previous studies where five HPV isolates had a variation of 10 out of 288 amino acids in the same region (22). HPV-F1 primer is likely to amplify the five isolates studied by She et al. (23) and Seifers et al. (22) based on their amino acid sequences. Only two out of five amino acid sequences from She et al. (23) and Seifers et al. (22) corresponding to the HPV-R1 primer are available. HPV-R1 primer is also likely to amplify other HPV isolates according to the two amino acid sequences (P83549, P83550) deposited at GenBank (23).
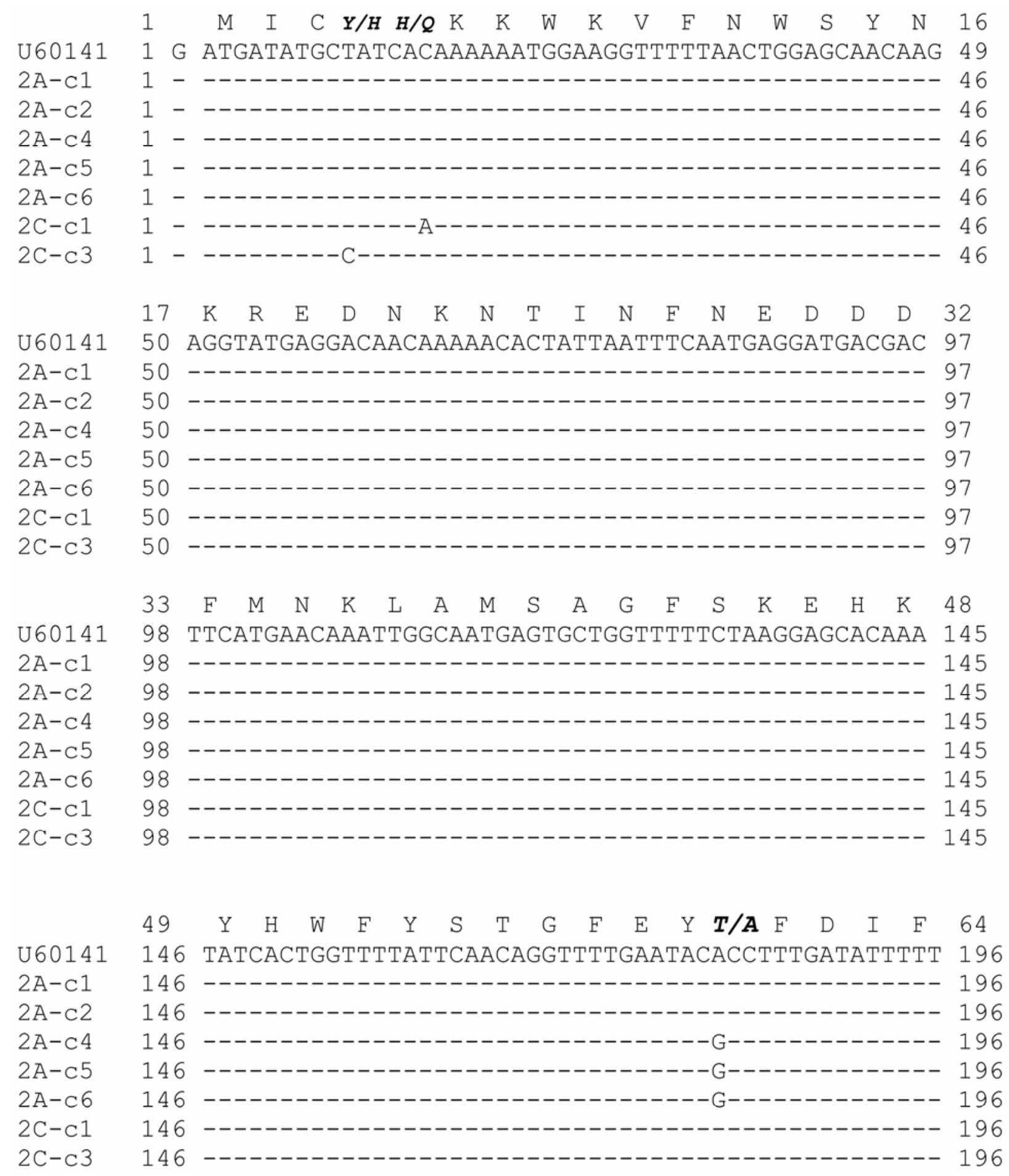

(continued on next page)

Fig. 5. Amino acids and nucleotide alignments of High Plains virus (HPV) variants from sweet corn compared with the HPV sequence available from GenBank (accession no. U60141). 
HPV was also detected by ELISA, although the Agdia system appeared to produce more reliable and consistent results. The Agdia ELISA and F(ab') protein A ELISA tests were carried out at different times of the year and with different preserved replicas of the same samples, which may be responsible for the variability found in the ELISA results.

The HPV variants from PCR products were found using SSCP analysis but not by restriction enzyme digests. The SSCP technique is able to differentiate one or two nucleotide mutations (18), whereas restriction enzyme digestions specifically target recognition sites. The SSCP result may be affected by the lack of fidelity during the error-prone PCR amplification process. The SSCP analysis in this study was repeated from four different PCR reactions, and the same polymorphisms were always observed (Fig. 4). Seifers et al. (22) also found some variability at the amino acid level of the 32-kDa protein of five HPV isolates from the United States using mass spectrometry. Results obtained using SSCP in this study and the mass spectrometry experiments (22) suggest the presence of a population of HPV. The SSCP technique could be useful for further studies at the nucleotide level on the population of the virus from different plant hosts and/or from the wheat curl mite vector.

Nucleotide changes resulted in the appearance of four amino acid substitutions (Fig. 5) that were not detected in the 99 amino acid sequence of five isolates determined by mass spectrometry (22), suggesting that the nucleotide alterations obtained in our study may be due to PCR amplification artifacts. The cloned HPV sequences represent a third of the HPV sequence available in GenBank. Further phylogenetic study of HPV isolates is needed for confirmation of the high amino acid similarity.

Based on the RT-PCR results, it is recommended that quarantine virus indexing scheme inspections be carried out when seedlings consist of at least five to six leaves. This allows symptoms to fully develop. Symptoms observed on HPVnegative samples may be due to nutrient deficiency such as interveinal iron chlorosis or the presence of another nonregulated seed transmissible virus such as Barley stripe mosaic virus (BSMV), but not WSMV, as seeds were certified free of this virus. In field grown conditions, more symptomatic plants may be observed as a result of more conducive environmental conditions and also the spread of other virus diseases including BSMV.

While Forster et al. (5) reported a seed transmission rate of $0.008 \%$, HPV in our studies was found in eight out of 50,655 seedlings, corresponding to a seed transmission of at least $0.016 \%$ (only 27 out of 50,655 seedlings were tested). Seeds from our study were also originally from the United States where HPV disease occurs $(7,9)$.

The wheat curl mite may transmit a population of HPV by feeding on various plant hosts. An HPV population may result from an adaptation to the mite and/or the plant host. Some wheat curl mites may transmit the virus better than others and some viruses may replicate better in some hosts than others. Seifers et al. (19) reported that the transmission of HPV isolates depends on the ability of the wheat curl mite vector to transmit the virus,

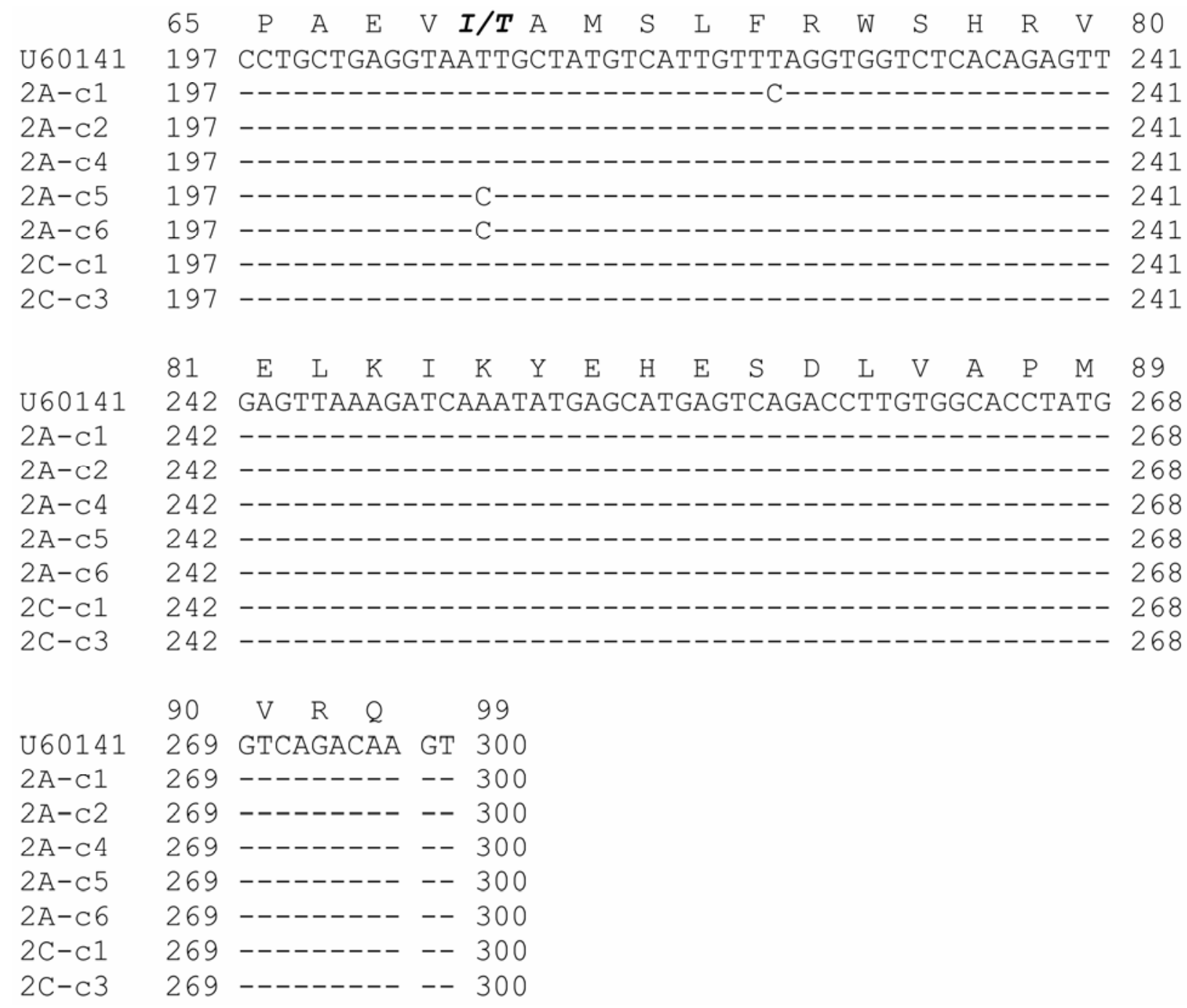

Fig. 5. (continued from previous page) 
rather than differences among HPV isolates. Similar results were observed with Citrus tristeza virus (CTV) on citrus, where strain variability and disease symptoms greatly depend on aphid transmissibility (16). Transmission of HPV by wheat curl mites on different hosts may also act as a bottleneck effect. CTV isolates from different countries and in different years showed a very high sequence identity, within the range to be classified as quasispecies (2).

The wheat curl mite is not present in New Zealand. The only mite reported in cereal in New Zealand is Tetranychus urticae (14), which could be a potential vector for HPV. Further transmission studies are required for evaluating the potential of disease spread by mites.

Seeds are the most likely pathway of HPV into New Zealand, and there appears to be a greater risk of importing HPVinfected seeds than previously thought. Cultivation of HPV-infected cereals may also result in an accumulation of the disease. In this study, a quarantine virus indexing scheme for HPV using specific procedures and reliable molecular methods of detection was developed to ensure that infected seed lines are not released from quarantine. The protocol is recommended in HPV testing for quarantine purposes or as a diagnostic tool for evaluating the spread of HPV where it is already present.

\section{ACKNOWLEDGMENTS}

We thank M. G. Redinbaugh (USDA-ARS Corn and Soybean Research) for providing the $\mathrm{F}\left(\mathrm{ab} \mathrm{b}^{\prime}\right) 2$ protein A ELISA protocol and the HPV positive control.

\section{LITERATURE CITED}

1. Ahn, K. K., Kim, K. S., Gergerich, R. C., Jensen, S. G., and Anderson, E. J. 1996. Comparative ultrastructure of double membranebound particles and inclusions associated with eriophyid mite-borne plant diseases of unknown aetiology: A potentially new group of plant viruses. J. Submicrosc. Cytopathol. Pathol. 28:345-355.

2. Albiach-Martí, M. R., Mawassi, M., Gowda, S., Satyanarayana, T., Hilf, M. E., Shanker, S., Almira, E. C., Vives, M. C., López, C., Guerri, J., Flores, R., Moreno, P., Garnsey, S. M., and Dawson, W. O. 2000. Sequences of Citrus tristeza virus separated in time and space are essentially identical. J. Virol. 74:6856-6865.

3. Blunt, T. D., and Hill, J. P. 2004. Increased incidence of seed transmission of High Plains virus disease in sweet corn. (Abstr.) Phytopathology 94:S8.

4. Flores, R., and Llacer, G. 1988. Isolation of a viroid-like RNA associated with peach latent mosaic disease. Acta Hortic. 235:325-332.

5. Forster, R. L., Seifers, D. L., Strausbaugh, C. A., Jensen, S. G., Ball, E. M., and Harvey, T. L. 2001. Seed transmission of the High Plains virus in sweet corn. Plant Dis. 85:696-699.

6. Harlow, E., and Lane, D. 1988. Antibodies: A Laboratory Manual. Cold Spring Harbor Laboratory, Cold Spring Harbor, NY.

7. Jensen, S. G. 1999. High plains virus - A new twist to an old story. (Abstr.) Phytopathology 89:S84.

8. Jensen, S. G., Fithian, W. A., Berry, J. A., Ball, E. M., and Hall, J. S. 1998. The High plains virus, representative of a new viral group with possible world wide distribution. Int. Congr. Plant Pathol., 7th. Edinburgh, UK. Abstr. 6.160.

9. Jensen, S. G., and Lane, L. C. 1994. A new virus disease of corn and wheat in the high plains. (Abstr.) Phytopathology 84:1158.

10. Jensen, S. G., Lane, L. C., and Seifers, D. L. 1996. A new disease of maize and wheat in the high plains. Plant Dis. 80:1387-1390.

11. Kumar, P. L., Duncan, G. H., Roberts, I. M., Jones, A. T., and Reddy, D. V. R. 2002. Cytopathology of Pigeonpea sterility mosaic virus in pigeonpea and Nicotiana benthamiana: Similarities with those of eriophyid mite-borne agents of undefined aetiology. Ann. Appl. Biol. 140:87-96.

12. Louie, R., Redinbaugh, M. G., Gordon, D. T., Abt, J. J., and Anderson, R. J. 2000. Maize necrotic streak virus, a new maize virus with similarity to species of the family Tombusviridae. Plant Dis. 84:1133-1139.

13. Mahmood, T., Hein, G. L., and Jensen, S. G.
1998. Mixed infection of hard red winter wheat with High Plains virus and wheat streak mosaic virus from wheat curl mites in $\mathrm{Ne}$ braska. Plant Dis. 82:311-315.

14. Manson, D. C. 1987. A list of New Zealand mites and their host plants. DSIR Bull. No. 240. C. W. Matthews, ed. DSIR Science Information Publishing Centre, Wellington, New Zealand.

15. Marçon, A., Kaeppler, S. M., and Jensen, S. G. 1997. Genetic variability among maize inbred lines for resistance to the high plains viruswheat streak mosaic virus complex. Plant Dis. 81:195-198.

16. Rocha-Pena, M. A., Lee, R. F., Lastra, R., Niblett, C. L., Ochoa-Corona, F. M., Garnsey, S. M., and Yokomi, R. K. 1995. Citrus tristeza virus and its aphid vector Toxoptera citricida. Plant Dis. 79:437-445.

17. Rozen, S., and Skaletsky, S. 2000. Primer3 on the WWW for general users and for biologist programmers. Pages 365-386 in: Bioinformatics Methods and Protocols: Methods in Molecular Biology. S. Krawetz and S. Misener, eds. Humana Press, Totowa, NJ.

18. Rubio, L., Ayllón, M. A., Guerri, J., Pappu, H. Niblett, C., and Moreno, P. 1996. Differentiation of Citrus tristeza closterovirus (CTV) isolates by single-strand confirmation polymorphism analysis of the coat protein gene. Ann. Appl. Biol. 129:479-489.

19. Seifers, D. L., Harvey, T. L., Louie, R., Gordon, D. T., and Martin, T. J. 2002. Differential transmission of isolates of the High Plains virus by different sources of wheat curl mites. Plant Dis. 86:138-142.

20. Seifers, D. L., Harvey, T. L., Martin, T. J., and Jensen, S. G. 1997. Identification of the whea curl mite as the vector of the High Plains virus of corn and wheat. Plant Dis. 81:1161-1166.

21. Seifers, D. L., Harvey, T. L., Martin, T. J., and Jensen, S. G. 1998. A partial host range of the High Plains virus of corn and wheat. Plant Dis. 82:875-879.

22. Seifers, D. L., She, Y.-M., Harvey, T. L., Martin, T. J., Haber, S., Ens, W., Standing, K. G., Louie, R., and Gordon, D. T. 2004. Biological and molecular variability among High Plains virus isolates. Plant Dis. 88:824-829.

23. She, Y.-M., Seifers, D. L., Haber, S., Ens, W., and Standing, K. G. 2004. Characterization of the agent of "High plains disease". J. Biol. Chem. 279:488-494. 